Santa Clara University

Scholar Commons

Civil Engineering

School of Engineering

6-2007

\title{
Uncertainty in hydrologic impacts of climate change in the Sierra Nevada, California under two emissions scenarios
}

Edwin P. Maurer

Santa Clara University, emaurer@scu.edu

Follow this and additional works at: https://scholarcommons.scu.edu/ceng

Part of the Civil and Environmental Engineering Commons

\section{Recommended Citation}

Maurer, E.P., 2007, Uncertainty in hydrologic impacts of climate change in the Sierra Nevada, California under two emissions scenarios, Climatic Change, Vol. 82, No. 3-4, 309-325, doi: 10.1007/s10584-006-9180-9

The final publication is available at Springer via https://doi.org/10.1007/s10584-006-9180-9.

This Article is brought to you for free and open access by the School of Engineering at Scholar Commons. It has been accepted for inclusion in Civil Engineering by an authorized administrator of Scholar Commons. For more information, please contact rscroggin@scu.edu. 
Uncertainty in hydrologic impacts of climate change in the Sierra Nevada Mountains, California under two emissions scenarios

\author{
Edwin P. Maurer
}

Assistant Professor

Civil Engineering Department

Santa Clara University

Santa Clara, CA 95053-0563

Tel: 408-554-2178

Fax: 408-554-5474

emaurer@engr.scu.edu

Submitted to Climatic Change

Date: 29 April 2005

Running Title: Hydrologic Impact Uncertainty in Sierra Nevada, California 


\begin{abstract}
A hydrologic model was driven by the climate projected by 11 GCMs under two emissions scenarios (the higher emission SRESA2 and the lower emission SRESB1) to investigate whether the projected hydrologic changes by 2071-2100 have a high statistical confidence, and to determine the confidence level that the A2 and B1 emissions scenarios produce differing impacts. There are highly significant average temperature increases by $2071-2100$ of $3.7^{\circ} \mathrm{C}$ under $\mathrm{A} 2$ and $2.4^{\circ} \mathrm{C}$ under $\mathrm{B} 1$; July increases are $5^{\circ} \mathrm{C}$ for $\mathrm{A} 2$ and $3^{\circ} \mathrm{C}$ for $\mathrm{B} 1$. Two high confidence hydrologic impacts are increasing Winter streamflow and decreasing late Spring and Summer flow. Less snow at the end of Winter is a confident projection, as is earlier arrival of the annual flow volume, which has important implications on California water management. The two emissions pathways show some differing impacts with high confidence: the degree of warming expected; the amount of decline in summer low flows; the shift in streamflow timing for higher elevation basins, with more extreme impacts under higher emissions in all cases. This indicates that future emissions scenarios play a significant role in the degree of impacts to water resources in California.
\end{abstract}




\section{Introduction}

Climate change is affecting the water resources on which populations in the Western U.S. rely (e.g. Mote et al., 2005; Stewart et al., 2005; Trenberth et al., 2003), and continued anthropogenic emissions of greenhouse gases will exacerbate these effects for future decades and centuries. (e.g., Dettinger et al, 2004; Hayhoe et al., 2004; Knowles and Cayan, 2004; Stewart et al., 2004) Recognizing the crucial role management of water resources plays in sustaining California’s economy (Draper et al, 2003), the high sensitivity of its ecosystems to climatic changes (Field et al., 1999), and the vulnerability of California's water supply to changes in precipitation or temperature, studies of the potential impact of climate change on California began nearly two decades ago. (Gleick, 1987; Lettenmaier and Gan, 1990).

The importance of this issue continues to generate considerable research using relatively coarse resolution Global Climate Models (GCMs) to drive land surface hydrology models (e.g., Brekke et al., 2004; Knowles and Cayan, 2004; Maurer and Duffy, 2005; Miller et al, 2003; Van Rheenan et al., 2004). Recent efforts using finer resolution regional climate models have attempted to define with more precision the spatial variability of anticipated changes in future hydroclimatology over California. (Kim et al., 2002; Kim, 2005;

Snyder et al., 2002). While there are many points of qualitative agreement between the wealth of studies on the topic, these studies tend to emphasize one or several selected potential outcomes, and the uncertainty in the projected impacts is not quantitatively addressed. 
Quantifying the uncertainties in projections of climate change and its impacts is essential for assisting California policy-makers and water managers in adopting coherent and informed response strategies reflecting the state of scientific understanding of the likelihood of outcomes. (Dettinger, 2004; Kiparski and Gleick, 2004) For assessing regional hydrologic impacts, one can consider four levels of uncertainty. The first three relate to the generation of regional climate information (Intergovernmental Panel on Climate Change, IPCC, 2001) and consist of uncertainty in the future emissions of greenhouse gases, differing responses of GCMs to the resulting concentrations of these gases, and the uncertainty added by the downscaling technique used to translate the coarse scale GCM output to a regional spatial scale. The fourth level of uncertainty relates to the selection and implementation of the land surface hydrology model. For regional hydrology impact studies, only recently have these differing sources of uncertainty been examined separately: for example Hayhoe et al. (2004) examined two GCMs and two emissions scenarios over California; Zierl and Bugmann (2005) evaluated hydrologic responses with four SRES scenarios using one GCM, and four GCMs under one emissions scenario.

Maurer and Duffy (2005) studied the projected regional impacts of rising $\mathrm{CO}_{2}$ levels on California streamflow using GCM simulations performed between 1995 and 2002, archived as part of the Coupled Model Intercomparison Project (CMIP, Covey et al, 2003; Meehl et al, 2000). They examined only the second level of uncertainty outlined above, that is, the differing sensitivities of different GCMs under identically changing 
atmospheric conditions (a $1 \%$ per year $\mathrm{CO}_{2}$ increase) to address the question of how variability in GCM responses affects the confidence with which we can expect different streamflow changes. In this study, more recent GCM simulations are used, reflecting the most recent improvements in model parameterzations and structures. In addition, the new GCM simulations are performed for many different SRES scenarios (rather than a fixed rate of increase in $\mathrm{CO}_{2}$ ), which allows comparison across different potential futures, addressing both the first and second levels of uncertainty discussed above.

Taking advantage of many new GCM simulations under different emissions scenarios, the following questions are posed: 1) What are the projected hydrologic impacts of climate change on Sierra Nevada mountain hydrology, and with what confidence, relative to the variability between GCMs, are these different from the base period of 1961-1990? 2) With what confidence are the impacts under the two scenarios considered here different at the end of the century? These questions are addressed by forcing a land surface hydrology model with the future climate projected by different GCMs, and creating an ensemble of hydrologic responses under each emissions scenario.

\section{Data and Methods}

\subsection{Study Region}

The area of focus for this study is California, which is depicted in Figure 1. In particular, the analyses that follow initially included four basins, the outlets of which are shown on 
Figure 1. The basins drain western slopes of the Sierra Nevada mountain range, supplying fresh water to the extensive system of dams and reservoirs serving the water demands of much of the state. All four points are at inflows to large reservoirs. Characteristics of the four points identified in Figure 1 are in Table 1, which shows the southern two basins (basins 3 and 4) contain more high elevation areas than the northern two (basins 1 and 2), and together a range of mean basin elevations is represented. Snow plays a crucial role in the management of seasonal water storage and delivery: on average the amount of water stored as snow in the Sierra Nevada on April 1, about $12.4 \mathrm{~km}^{3}$ (Hayhoe et al., 2004), is more than twice the total capacity of Lake Shasta, the largest manmade reservoir in California. Since one of the principal impacts of climate change on California water resources is on snowpack, and hydrologic changes exhibit a strong dependence on elevation (Knowles and Cayan, 2004), the selection of basins included in this study is designed to illuminate these differing responses.

\subsection{Global Climate Models}

Many international modeling groups are completing simulations of present climate and future climate under selected IPCC SRES scenarios in preparation for the IPCC 4th Assessment Report (AR4). (Meehl et al., 2005) For this study, simulations are used from the 11 GCMs that by March 1, 2005 had completed at least one simulation each of the $20^{\text {th }}$ century climate and future climate (through 2100) using emissions scenarios SRES $\mathrm{A} 2$ and B1. While A2 does not represent the highest $\mathrm{CO}_{2}$ emissions (at least through 2100) of the SRES scenarios (IPCC, 2001), it is the highest emission scenario being 
archived as part of CMIP. As such, although it is by no means a "worst case," it does represent the higher emission case in this study. B1 assumes an increasing reliance on clean and resource-efficient technologies, and represents the best case of the SRES scenarios. (IPCC, 2001)

The GCMs included in this study are shown in Table 2. For each GCM, and each period

( $20^{\text {th }}$ century, scenarios A2, B1) monthly precipitation $(\mathrm{P})$ and temperature $(\mathrm{T})$ data were obtained from the IPCC AR4 data archive hosted by the Program for Climate Model Diagnosis and Intercomparison. Where a GCM has archived more than one simulation under a particular scenario, the ensemble average is used, so as not to bias the population of GCMs toward any specific model. All GCMs are interpolated onto a common $2^{\circ}$ latitude-longitude grid, approximately equal to the spatial scale of the finest GCMs included in this study, to standardize the analysis that follows.

\subsubsection{GCM bias correction and spatial downscaling}

While large scale patterns of precipitation and temperature simulated by state-of-the-art GCMs can be realistic, even the best models display biases on regional scales that are large enough to confound studies of the hydrologic impacts of climate change. To cope with this, many different techniques have been employed to process the raw GCM output to retain the large scale signal of the evolving climate simulated by the GCM while reproducing historical climate patterns on the landscape at local scales, an essential characteristic for meaningful hydrologic analysis (Wood et al., 2004). One method used 
in many studies is to use a shift or scaling factor derived by comparing a climate model's future precipitation or temperature to its climatology, and to apply this shift to a historical record (e.g., Miller et al., 2003; Lettenmaier and Gan, 1990). While this method effectively removes the bias of the mean GCM climatology from the future climate, it does not address the potential bias in the variability of the climate model and constrains inter-annual variability to be constant.

For this study, we employ a bias correction technique originally developed by Wood et al. (2002) for using global model forecast output for long-range streamflow forecasting. This technique was later adapted for use in studies examining the hydrologic impacts of climate change (Hayhoe et al., 2004; Maurer and Duffy, 2005; Payne et al., 2004; Van Rheenan et al., 2004). This is an empirical statistical technique that maps precipitation and temperature during a historical period (1950-1999 for this study) from the GCM to the concurrent historical record. The historical data used in this study is gridded National Climatic Data Center Cooperative Observer station data, developed as described in Maurer et al. (2002), and aggregated up to a $2^{\circ}$ latitude-longitude spatial resolution. For $\mathrm{P}$ and $\mathrm{T}$, cumulative distribution functions are built for each of 12 months for each of the $2^{\circ}$ grid cells for both the gridded observations and each GCM for the climatological period. GCM quantiles are then mapped onto the climatological CDF for the entire simulation period. For example, if for one grid point the GCM P value in January of 2050 is equal to the median GCM value for January for 1950-1999, it is transformed to the median value for the gridded January observations for 1950-1999. For T, the linear trend is removed prior to this bias correction and replaced afterward, to avoid increasing sampling at the 
tails of the CDF as temperatures rise. Thus, the probability distribution of observations is reproduced by the bias corrected climate model data for the overlapping climatological period, while both the mean and variability of future climate can evolve according to GCM projections.

Climate model output, which at $200-500 \mathrm{~km}$ is at too large a scale for basin scale hydrologic analysis, requires spatial downscaling prior to its use in a hydrology model. This can be done with dynamical or statistical methods (see for example Benestad, 2001; Mearns et al., 2001). The main disadvantage of dynamic downscaling is the computational effort involved, which renders its use impractical for extended transient simulations of multiple emissions scenarios, as used in this study. The method used in this study is that applied by Wood et al. (2002), which for each month interpolates the bias corrected GCM anomalies, expressed as a ratio (for precipitation) and shift (for temperature) relative to the climatological period at each $2^{\circ} \mathrm{GCM}$ grid cell to the centers of 1/8 degree hydrologic model grid cells over California. These factors are then applied to the $1 / 8$ degree gridded precipitation and temperature. The combined bias correction/spatial downscaling method used in this study has been shown to compare favorably to different statistical and dynamic downscaling techniques (Wood et al., 2004) in the context of hydrologic impact studies. 


\subsection{Hydrologic Model Simulations}

The hydrologic model used in this study is the variable infiltration capacity (VIC) model (Liang et al. 1994; 1996). VIC is a macroscale, distributed, physically-based hydrologic model that balances both surface energy and water over a grid mesh, typically at resolutions ranging from a fraction of a degree to several degrees latitude by longitude. One distinguishing characteristic of the VIC model is its use of a "mosaic" scheme, allowing a statistical representation of the sub-grid scale spatial variability in topography and vegetation/land cover, which is especially important when simulating the accumulation and ablation of snow in more complex terrain. To account for subgrid variability in infiltration, the VIC model uses a scheme based on the work by Zhao et al. (1980). The VIC model also features a nonlinear mechanism for simulating slow (baseflow) runoff response, and explicit treatment of vegetation effects on the surface energy balance. The resulting runoff at each grid cell is routed through a defined river system using the algorithm developed by Lohmann et al. (1996). The VIC model has been successfully applied in many settings, from global to river basin scale (e.g., Abdulla et al., 1996; Maurer et al. 2001, 2002; Nijssen et al., 1997, 2001), as well as in several studies of hydrologic impacts of climate change (Christensen et al, 2004; Hayhoe et al., 2004; Maurer and Duffy, 2005; Payne et al., 2004; Wood et al., 2004). For this study, the model was run at a 1/8-degree resolution (measuring about $150 \mathrm{~km}^{2}$ per grid cell) over the Sacramento-San Joaquin river system, using the identical parameterization as Van Rheenan et al. (2004). 


\subsection{Assessing uncertainty in hydrologic impact projections}

Following the approach of Maurer and Duffy (2005), results for each impact, in this case streamflow and snowpack, for all GCMs are assembled for each emissions scenario. For each variable, the mean monthly value for each GCM for each of three defined periods is calculated, and these values for each GCM are combined by variable and period into ensembles. These ensembles of hydrologic variables are statistically analyzed using 2sided t-tests to determine the confidence level for the change from the climatological period (1961-1990). In addition, the confidence with which one can claim that the two scenarios give different results is determined.

\section{Results and Discussion}

For a domain including all four of the study basins the hydrologic model produced complete estimates of the water budget using each GCM. These were then summarized for four periods: the base period 1961-1990, 2011-2040, 2041-2070, and 2071-2100. For one basin, under the A2 scenario, the results for the latter two periods are plotted in Figure 2. This shows that winter P increases but is quite variable between the models, while the $\mathrm{T}$ increases appear more consistent. In general the impact on flow of these climatic changes is that winter flows increase and late spring and early summer flows decrease, with greater disagreement between models during the transition between the two. Declining snow water equivalent (SWE) is clear, and is more severe later in the century as temperatures continue to rise. 


\subsection{Precipitation and temperature changes}

To verify statistically the observations above related to $\mathrm{T}$ and $\mathrm{P}$, and use both emissions scenarios, Tables 3 and 4 are shown. Note that the 90\% and 95\% confidence thresholds highlighted in the Tables are comparable to the National Assessment Synthesis Team (2000) classification of "very likely or very probable" impacts as those with confidence $>90 \%$. Since the changes in the $\mathrm{P}$ and $\mathrm{T}$ forcing were found to be remarkably consistent between basins, only the northern and southernmost basins are included in this section. Each Table shows for each month and for the annual total the mean of the 1961-1990 base period and the change to each of the three future periods. Annual average $\mathrm{P}$ increases significantly by about $10 \%$ in the North early in the $21^{\text {st }}$ century, with most of the increase in December-February. A significant decline in April-June P appears later in the century, and the increase in Winter P persists. Table 4 shows a similar pattern toward the South, though with sharper declines in April-June P than in the North. While not shown in the tables, the $\mathrm{T}$ projections in the North and South are very close and are highly significant, even as early as 2011-2040. By the end of the $21^{\text {st }}$ century, average annual T rises by $3.6-3.8^{\circ} \mathrm{C}$ for the A2 scenario, and $2.3-2.4^{\circ} \mathrm{C}$ for $\mathrm{B} 1$, with the greatest warming being in July with $3.0-3.1^{\circ} \mathrm{C}$ for the $\mathrm{B} 1$ scenario and $5.0-5.1^{\circ} \mathrm{C}$ for A2. While these changes are broader scale, showing high consistency between the North and South, the differing characters of the basins produces different hydrologic responses. 
To assess the separation of the future climate under the two SRES scenarios, Table 5 shows the statistical confidence with which the 2071-2100 T and P differ for the two scenarios. While both scenarios show highly significant changes in $\mathrm{T}$ by the end of the century, Table 5 also shows that, with the exception of March and April, the temperature rises are smaller for B1 as compared to A2 with high statistical confidence. For March and April, the confidence that the future $\mathrm{T}$ under the two scenarios is different is below 90\% but is higher for the higher elevation basins, suggesting that during these months Tdriven effects under the two scenarios may differentiate more by elevation.

For the annual average $\mathrm{P}$ the two scenarios produce statistically indistinguishable futures. Even at the monthly scale the differences in projected P for 2071-2100 under the two scenarios are not generally different with a high degree of confidence. The exception is March and April, where the decline in P projected under the A2 scenario is significantly greater than under B1, exceeding 90\% confidence for the higher elevation basins.

\subsection{Streamflow and snow changes}

The above changes in $\mathrm{P}$ and $\mathrm{T}$ produce changes in the hydrologic response of the landscape, which are reflected in the streamflow changes shown in Tables 6 and 7. For the lower elevation gauges, Table 6 shows high statistical confidence for the increases in December-March flows in all time periods. This reflects the increasing P during these months under both scenarios. The increases in December-March flows are markedly greater for the A2 scenario than B1. For A2, May-September flows decline, and both the 
magnitude and the statistical confidence increase through the $21^{\text {st }}$ century, since these changes are largely T-driven. For B1 the same pattern is evident, but is limited to MayAugust, and by the end of the century the declines in streamflow are uniformly less severe than under A2 and generally of lower confidence. Decreased summer flows in 2071-2100 have more limited duration under the B1 scenario than under A2, with 4 consecutive months with flow declines at $>95 \%$ confidence, compared to 5 months for A2. The increases in winter flow more than offset the declines in summer, producing an increase in annual flow for both basins, with the increase being lower for B1 and for the higher elevation basin.

For the southern 2 basins at higher elevation, Table 7 continues the same pattern of annual flow changes, where annual flow increases are lower in magnitude for B1, and are lower in magnitude for the higher elevation basin. The southern basins show increased flows through April-May despite decreasing P. This is in contrast to the lower elevation Northern basins, where flow increases continue only through March-April, with smaller declines and even some increasing $\mathrm{P}$. This illustrates the interplay between $\mathrm{T}$ and $\mathrm{P}$ changes, where at higher elevation increases in December-February P can be stored as snow, later to augment flow. The statistically significant declines in streamflow for 20712100, are limited to 3 months in duration, in contrast to 4 months for each of the Northern basins.

The two scenarios do not produce streamflows differing with a high degree of confidence, as shown in Table 8. The declines in August-September flow display the 
highest confidence that $\mathrm{A} 2$ and $\mathrm{B} 1$ result in different flow responses, with A2 showing sharper declines. The confidence in the difference between the scenarios is lower for the higher elevation basins showing declining sensitivity to the differences between A2 and B1 for the low flow period.

Table 9 summarizes the change in April 1 SWE for each basin for each time period. April 1 snowpack is a widely used indicator of the water available as summer supply in the Western U.S. (e.g., Hamlet and Lettenmaier, 1999, Knowles and Cayan, 2004); a decrease indicates either earlier melt and/or reduced winter snow accumulation. There is a clear pattern of lower snow loss for the Southern, higher elevation basins, showing that rising temperatures at higher elevations are less likely to bring temperatures above freezing and cause snow melt. Although there is significantly greater warming under A2, December-February P increases more dramatically for A2 than under B1 which results in greater April 1 SWE losses under the lower emission B1 scenario though mid-century. By the end of the $21^{\text {st }}$ century, the $\mathrm{T}$ changes have become dominant, and B1 shows 810\% less April 1 SWE loss compared to A2, and there is high confidence in all projected losses. The confidence level that the April 1 SWE loss projected under the two scenarios differs is below $60 \%$ (using a 2-sided t-test) for all basins, showing that although the impacts on April 1 SWE are high, the scenarios do not show a statistically significant difference by 2071-2100. Though not shown, the projected declines in DecemberFebruary monthly average SWE are $30-45 \%$ for B1 and $50-60 \%$ for A2 for the lower elevation basins, and for this measure the difference between the changes under A2 and B1 generally differ with higher confidence levels of over $80 \%$. 
The earlier melt due to rising temperatures produces a shift in the date of the centroid of the annual flow volume, which is calculated using the center-of-mass approach of Stewart et al. (2004) and is shown in Table 10. Due to the compounding effects of increasing Winter P, decreasing Spring P, more P falling as rain and earlier snow melt under higher $\mathrm{T}$, the shift in the timing of the annual hydrograph is highly confident for all basins and periods. The continuing shift to earlier arrival of runoff later in the $21^{\text {st }}$ century is robust for all basins. For the lower elevation basins, the difference between the shift for the B1 and A2 scenarios for 2071-2100 is only 4 days, hence the confidence that the response differs under the two scenarios is low $(<60 \%)$. In contrast, for the higher elevation basins the difference is $11-12$ days, and there is greater than $90 \%$ confidence that the impact under A2 is more dramatic than under B1.

\section{Conclusions}

For four basins in the Sierra Nevada Mountains in California, the simulated hydrologic impacts of future climate projected by 11 GCMs forced under two SRES emissions scenarios, a higher emission A2 and lower emission B1, were examined for statistical significance. While these scenarios do not represent worst and best case of possible emissions scenarios, of the selected SRES scenarios available for this study, they do represent the generally bounding scenarios for $21^{\text {st }}$ century emissions. With this structure, this study addresses only uncertainty related to inter-GCM and inter-emissions scenario variability, not uncertainty due to the hydrology model transforming climate to 
streamflow. The two questions posed for this study are whether (and when) the projected hydrologic impacts have high statistical confidence (relative to the variability between GCMs), and whether the impacts under the two scenarios differs with high confidence.

Temperature (T) shows highly significant increases over 1961-1990 levels, even early in the $21^{\text {st }}$ century. By $2071-2100$ T rises by an average of $3.7^{\circ} \mathrm{C}$ under $\mathrm{A} 2$ and $2.4^{\circ} \mathrm{C}$ under B1, with July temperatures rising most dramatically by $5^{\circ} \mathrm{C}$ for $\mathrm{A} 2$ and $3{ }^{\circ} \mathrm{C}$ for B1. The difference between the T increases, between 2071-2100 and 1961-1990, under A2 and B1 are highly significant. This indicates it can be confidently stated that the emissions pathway we follow significantly determines the future temperature experienced in the study region.

The same cannot be claimed so broadly for precipitation (P). Increases in Winter P and smaller decreases in Spring P are projected, with higher confidence under A2 than B1, especially by 2071-2100. While annual P does not differ between the emissions scenarios, decreases in April-May P are significantly greater for A2 than B1.

For streamflow at the basin outlets, flow increases for December-March, and through April-May for higher elevation basins. Flows decline for May-September in the lower elevation basins, and June-October at higher elevations. Increases in Winter and decreases in Summer flow are both of greater magnitude under A2 than B1. The highest confidence in the differing response under A2 and B1 are for August-September declines in streamflow, where the decreases are sharper under A2 than B1. 
By 2071-2100, the 30-69\% losses in April 1 snow water equivalent (SWE) are highly significant for all basins, with greater losses at lower elevations. The approximately 8$10 \%$ greater losses under A2 than B1 is not high confidence, showing the variability in results for different GCMs is larger for this variable.

The combined effects of changes in P, T and SWE result in an earlier arrival of the annual flow volume by as much as 40 days by 2071-2100. For the high elevation basins, the difference in this shift for B1 is significantly less than for A2.

In summary, as temperatures rise through the $21^{\text {st }}$ century we can expect with high confidence an increase in winter streamflow from the Sierra Nevada, due at least partly to increasing winter P, and a decrease in late Spring and Summer flow, which has important implications for California water management. We can confidently expect to have less water stored as snow at the end of winter, and we will expect an earlier arrival of the water, with implications on how reservoirs are managed. The emissions pathway, whether A2 or B1, shows some important differences in impacts, especially on the degree of warming expected, the decline in summer low flows, and the shift in streamflow timing for higher elevation basins, indicating that our emissions future determines to some extent the degree of impacts to water resources in California. 


\section{Acknowledgements}

The international modeling groups are acknowledged for providing their data for analysis, the Program for Climate Model Diagnosis and Intercomparison (PCMDI) for collecting and archiving the model data, the JSC/CLIVAR Working Group on Coupled Modelling (WGCM) and their Coupled Model Intercomparison Project (CMIP) and Climate Simulation Panel for organizing the model data analysis activity, and the IPCC WG1 TSU for technical support. The IPCC Data Archive at Lawrence Livermore National Laboratory is supported by the Office of Science, U.S. Department of Energy. 


\section{References}

Abdulla, F.A., Lettenmaier, D.P., Wood, E.F., and Smith, J.A.: 1996, ‘Application of a macroscale hydrologic model to estimate the water balance of the Arkansas-Red River basin’, J. Geophys. Res., 101(D3), 7449-7459.

Benestad, R.E.: 2001, ‘A comparison between two empirical downscaling strategies’, Intl. J. of Climatology 21, 1645-1668.

Brekke, L.D., Miller, N.L., Bashford, K.E., Quinn, N.W.T., and Dracup, J.A.: 2004, 'Climate change impacts uncertainty for water resources in the San Joaquin River basin, California', J. American Water Resources Association 40, 149-164.

Christensen, N.S., Wood, A.W., Voisin, N., Lettenmaier, D.P., and Palmer, R.N.: 2004, 'The Effects of Climate Change on the Hydrology and Water Resources of the Colorado River Basin’, Climatic Change 62, 337-363

Covey, C., AchutaRao, K.M., Cubasch, U., Jones, P., Lambert, S.J., Mann, M.E., Phillips, T.J., and Taylor, K.E.: 2003: ‘An overview of results from the Coupled Model Intercomparison Project (CMIP)', Global and Planetary Change 37, 103133.

Delworth, T.L. and 40 co-authors: 2005, ‘GFDL s CM2 global coupled climate models Part 1: Formulation and simulation characteristics', Journal of Climate (in revision)

Dettinger, M., 2004: 'From climate-change spaghetti to climate-change distribution', Discussion Paper 500-04-028, California Energy Commission, Sacramento, California, 20 pp. 
Dettinger, M.D., Cayan, D.R., Meyer, M.K. and Jeton, A.E.: 2004, 'Simulated hydrologic responses to climate variations and change in the Merced, Carson, and American River basins, Sierra Nevada, California, 1900-2099’, Climatic Change 62, 283317.

Diansky N.A. and Volodin E.M: 2002. 'Simulation of present-day climate with a coupled Atmosphere-ocean general circulation model', Izv. Atmos. Ocean. Phys. (Engl. Transl.) 38(6), 732-747.

Draper, A.J., Jenkins, M.W, Kirby, K.W., Lund, J.R., and Howitt, R.E.: 2003. 'Economic-Engineering Optimization for California Water Management', Journal of Water Resources Planning and Management 129(3), 155 - 164.

Field, C.B., Daily, G.C., Davis, F.W., Gaines, S., Matson, P.A., Melack, J., and Miller, N.L.: 1999, 'Confronting climate change in California: Ecological impacts on the golden state', Union of Concerned Scientists, Cambridge, MA, and Ecological Society of America, Washington, D.C., 63 pp.

Gleick, P.H., 1987, The development and testing of a water balance model for climate impact assessment: Modeling the Sacramento basin, Water Resources Res. 23, 1049-1061.

Gordon, C., Cooper, C., Senior, C.A., Banks, H.T., Gregory, J.M., Johns, T.C., Mitchell, J.F.B. and Wood, R.A.: 2000, 'The simulation of SST, sea ice extents and ocean heat transports in a version of the Hadley Centre coupled model without flux adjustments', Clim. Dyn. 16, 147-168.

Gordon, H.B., Rotstayn, L.D., McGregor, J.L., Dix, M.R., E.A. Kowalczyk, O’Farrell, S.P., Waterman, L.J., Hirst, A.C., Wilson, S.G., Collier, M.A., Watterson, I.G., 
and Elliott, T.I.: 2002, 'The CSIRO Mk3 Climate System Model’, CSIRO Atmospheric Research Technical Paper No.60, CSIRO. Division of Atmospheric Research, Victoria, Australia, 130 pp.

Hamlet, A.F. and Lettenmaier, D.P.: 1999, 'Effects of climate change on hydrology and water resources of the Columbia River basin’, J. American Water Resour. Assoc. $35,1597-1624$.

Hayhoe, K., Cayan, D., Field, C., Frumhoff, P., Maurer, E., Miller, N., Moser, S., Schneider, S., Cahill, K., Cleland, E., Dale, L., Drapek, R., Hanemann, R.M., Kalkstein, L., Lenihan, J., Lunch, C., Neilson, R., Sheridan, S., and Verville, J.: 2004, 'Emissions pathways, climate change, and impacts on California', Proceedings of the National Academy of Sciences (PNAS) 101 (34), 1242212427.

IPCC, 2001: Climate Change 2001: ‘The Scientific Basis. Contribution of Working Group I to the Third Assessment Report of the Intergovernmental Panel on Climate Change’, Houghton, J.T., Ding, Y., Griggs, D.J., Noguer, M., van der Linden, P.J., Dai, X., Maskell, K., and Johnson , C.A. (eds.). Cambridge University Press, 881pp.

IPSL: 2005, 'The new IPSL climate system model: IPSL-CM4', Institut Pierre Simon Laplace des Sciences de l’Environnement Global, Paris, France, 73 pp. Jungclaus, J.H., Botzet, M., Haak, H., Keenlyside, N., Luo, J.-J., Latif, M., Marotzke, J., Mikolajewicz, U., and Roeckner, E.: 2005, ‘Ocean circulation and tropical variability in the AOGCM ECHAM5/MPI-OM', J. Climate (in review) 
K-1 model developers: 2004, 'K-1 coupled model (MIROC) description’, K-1 technical report, 1, H. Hasumi and Emori , S. (eds.), Center for Climate System Research, University of Tokyo, 34pp.

Kim, J.: 2005, 'A projection of the effects of the climate change induced by increased CO2 on extreme hydrologic events in the Western U.S.', Climatic Change 68, 153-168.

Kim, J., Kim, T.K., Arritt, R.W., and Miller, N.L.: 2002, 'Impacts of increased CO2 on the hydroclimate of the western United States’, J. Climate 15, 1926-1943.

Kiparski, M. and Gleick, P.H.: 2004, 'Climate change and California water resources, In:The World’s Water 2004-2005’, P.H. Gleick, Ed., Island Press, Washington D.C., pp. 157-188.

Knowles, N. and Cayan, D.R.: 2004, 'Elevational dependence of projected hydrologic changes in the San Francisco estuary and watershed', Climatic Change 62, 319336.

Lettenmaier, D.P. and Gan, T.Y.: 1990, 'Hydrologic Sensitivities of the Sacramento-San Joaquin River basin, California, to global warming', Water Resources Res. 26, 6986.

Liang, X., Lettenmaier, D.P., Wood, E., and Burges, S.J.: 1994, ‘A simple hydrologically based model of land surface water and energy fluxes for general circulation models', J. Geophys. Res., 99 (D7), 14,415-14,428.

Liang, X., Lettenmaier, D. P., and Wood, E. F.: 1996, 'One-dimensional statistical dynamic representation of subgrid spatial variability of precipitation in the two- 
layer variable infiltration capacity model', J. Geophys. Res., 101 (D16), 21,40321,422 .

Lohmann, D., Nolte-Holube, R., and Raschke, E.: 1996, ‘A large-scale horizontal routing model to be coupled to land surface parameterization schemes', Tellus, 48A, 708721.

Maurer, E.P. and Duffy, P.B.: 2005, 'Uncertainty in projections of streamflow changes due to climate change in California', Geophys. Research. Let. 32, doi:10.1029/2004GL021462

Maurer, E.P., Wood, A.W., Adam, J.C., Lettenmaier, D.P., and Nijssen, B.: 2002, ‘A Long-Term Hydrologically-Based Data Set of Land Surface Fluxes and States for the Conterminous United States', J. Climate 15(22), 3237-3251.

Maurer, E.P., O'Donnell, G.M., Lettenmaier, D.P., and Roads, J.O.: 2001, 'Evaluation of the Land Surface Water Budget in NCEP/NCAR and NCEP/DOE Reanalyses using an Off-line Hydrologic Model’, J. Geophys. Res.,106 (D16), 17,841-17,862

Mearns, L.O., Hulme, M., Carter, T.R., Leemans, R., Lal, M., and Whetton, P.: 2001, 'Climate scenario development', in: Climate Change 2001: The scientific basis. Contribution of working group 1 to the Third Assessment Report of the Intergovernmental Panel on Climate Change, edited by J.T. Houghton et al., Cambridge Univ. Press, New York, pp. 739-768.

Meehl, G.A., Covey, C., McAvaney, B., Latif, M., and Stoufer, R.J.: 2005, 'Overview of the coupled model intercomparison project', Bull. American Meteorol. Soc. 86, 89-93. 
Meehl, G.A., Boer, G.J., Covey, C., Latif, M., and Stouffer, R.J.: 2000, ‘The Coupled Model Intercomparison Project (CMIP)'. Bulletin of the American Meteorological Society, 81(2), 313-318.

Miller, N.L., Bashford , K.E. and Strem, E.: 2003, 'Potential impacts of climate change on California hydrology’, J. American Water Resources Assoc. 39, 771-784.

Mote, P.W., Hamlet, A.F., Clark, M.P., and Lettenmaier, D.P.: 2005, 'Declining mountain snowpack in Western North America', Bull. American Meteorol. Soc. 86, 39-49.

Nijssen, B., Lettenmaier, D.P., Liang, X., Wetzel, S.W., and Wood, E.: 1997, ‘Streamflow simulation for continental-scale basins', Water Resour. Res., 33(4), 711-724.

Nijssen, B., O'Donnell, G.M., Lettenmaier, D.P, Lohmann, D., and Wood, E.F.: 2001, 'Predicting the discharge of global rivers', J. Clim. 14, 1790-1808.

Payne, J.T., Wood, A.W., Hamlet, A.F., Palmer, R.N. and Lettenmaier, D.P.: 2004, 'Mitigating the effects of climate change on the water resources of the Columbia River basin’, Climatic Change 62, 233-256

Russell, G. L., Miller, J.R., and Rind, D.: 1995, ‘A coupled atmosphere-ocean model for transient climate change studies', Atmos. Ocean, 33, 683-730.

Russell, G. L., Miller, J.R., Rind, D., Ruedy, R.A., Schmidt, G.A., and Sheth, S.: 2000, 'Comparison of model and observed regional temperature changes during the past 40 years’ J. Geophys. Res. 105, 14891-14898. 
Salas-Mélia, D., Chauvin, F., Déqué, M., Douville, H., Gueremy, J.F., Marquet, P., Planton, S., Royer , J.F.and Tyteca, S.: 2005, 'Description and validation of the CNRM-CM3 global coupled model', Climate Dynamics (in review).

Snyder, M.A., Bell, J.L., Sloan, L.C., Duffy , P.B. and Govindasamy, B.: 2002, 'Climate responses to a doubling of atmospheric carbon dioxide for a climatically vulnerable region’, Geophys. Research. Letters 29 (11) 10.1029/2001GL014431.

Stewart, I.T., Cayan, D.R., and Dettinger, M.D.: 2004, 'Changes in snowmelt runoff timing in Western North America under a 'business as usual' climate change scenario’, Climatic Change 62, 217-232.

Stewart, I., Cayan, D.R., and Dettinger, M.D.: 2005, 'Changes toward Earlier Streamflow Timing across Western North America', J. Climate (in press).

Trenberth, K.E., Dai, A., Rasmussen, R.M., and Parsons, D.B.: 2003, 'The changing character of precipitation', Bulletin of the American Meteorological Society, 84, 1205-1217.

National Assessment Synthesis Team, 2000: 'Climate Change Impacts on the United States: The Potential Consequences of Climate Variability and Change on Water Resources of the United States', US Global Change Research Program, Washington, D.C., 151 pp.

Van Rheenen, N.T., Wood, A.W., Palmer, R.N., and Lettenmaier, D.P.: 2004, 'Potential implications of PCM climate change scenarios for California hydrology and water resources’, Climatic Change 62, 257-281

Washington, W.M., Weatherly, J.W., Meehl, G.A., Semtner, A.J., Bettge, T.W., Craig, A.P., Strand, W.G., Arblaster, J., Wayland, V.B., James, R., and Zhang, Y.: 2000, 
'Parallel climate model (PCM) control and transient simulations', Climate Dynamics 16. 755-774

Wood, A.W., Leung, L.R., Sridhar, V., and Lettenmaier, D.P.: 2004, 'Hydrologic implications of dynamical and statistical approaches to downscaling climate model outputs', Climatic Change 62, 189-216

Wood, A.W., Maurer, E.P., Kumar, A., and Lettenmaier, D.P.: 2002, ‘Long range experimental hydrologic forecasting for the eastern U.S.', J. Geophys. Res. 107(D20), 4429.

Yukimoto, S., Noda, A., Kitoh A., Sugi, M., Kitamura, Y., Hosaka, M., Shibata, K., Maeda, S., and Uchiyama, T.: 2001, 'The New Meteorological Research Institute Coupled GCM (MRI-CGCM2), — Model climate and variability —', Papers in Meteorology and Geophysics, 51, 47-88.

Zhao, R.-J., Fang, L.-R., Liu, X.-R., and Zhang, Q.-S.: 1980, 'The Xinanjiang model’, in Hydrological Forecasting, Proceedings, Oxford Symposium, IAHS Publ. 129, 351-356.

Zierl, B. and Bugmann, H.: 2005, 'Global change impacts on hydrological processes in Alpine Catchments', Water Resources Res. 41, doi:10:1029/2004WR003447. 


\section{List of Figures}

Figure 1 - Location of the outlets to the four basins included in this study.

Figure 2 - For one basin, the streamflow at the basin average precipitation and temperature, streamflow at the outlet point , and basin average snow water equivalent averaged over two 30-year periods. 


\section{List of Tables}

Table 1 - Locations and characteristics of the four basins in this study.

Table 2 - GCMs included in this study.

Table 3 - P summary statistics for the Basin 1 Feather River at Oroville. Values in italics are significantly different from the 1961-1990 mean at a 90\% confidence level, based on a 2-sided t-test for differences in the mean. Bold italics differ with 95\% confidence.

Table 4 - Same as Table 3, but for Basin 4. Kings R at Pine Flat Dam.

Table 5 - Confidence that the A2 and B1 mean P and T differ for 2071-2100. Confidence is determined with a 2-sided t-test for differences in mean. Basin numbering is as in Table 1.

Table 6 - Monthly and annual mean flow and percent change from the mean for the North (lower elevation) two gauges. Bold and italics signify the same confidence as for Table 2. Basin numbering is as in Table 1.

Table 7 - Same as for Table 6, but for the South two gauges at higher elevation.

Table 8 - Confidence that the mean flow for the A2 and B1 scenarios differ for 20712100. Confidence is determined with a 2-sided t-test for differences in mean. Basin numbering is as in Table 1.

Table 9 - Mean April 1 SWE and percent change. Bold and Italics are used identically to Table 3.

Table 10 - Date of the centroid of the annual flow volume, and the shift in days. Mean is in day of year (January 1=1). 
Table 1 - Locations and characteristics of the four basins in this study.

\begin{tabular}{l|c} 
Characteristic & Outlet point and basin characteristics
\end{tabular}

\begin{tabular}{l|c|c|c|c}
\hline Site Name & $\begin{array}{c}\text { 1. Feather R at } \\
\text { Oroville }\end{array}$ & $\begin{array}{c}\text { 2. American R } \\
\text { at Folsom Dam }\end{array}$ & $\begin{array}{c}\text { 3. Tuolumne at } \\
\text { New Don Pedro } \\
\text { Res }\end{array}$ & $\begin{array}{c}\text { 4. Kings R. at } \\
\text { Pine Flat Dam }\end{array}$ \\
\hline Latitude & 39.522 & 38.683 & 37.666 & 36.831 \\
\hline Longitude & -121.547 & -121.183 & -120.441 & -119.335 \\
\hline $\begin{array}{l}\text { Drainage Area, km } \\
\text { Mean Basin }\end{array}$ & 9350 & 4850 & 3970 & 4000 \\
$\begin{array}{l}\text { Elevation, m } \\
\text { Max Basin } \\
\text { Elevation, m }\end{array}$ & 1553 & 1335 & 1755 & 2196 \\
\hline $\begin{array}{l}\text { Min Basin } \\
\text { Elevation, } \mathrm{m}\end{array}$ & 2655 & 3009 & 3802 & 4086 \\
\hline
\end{tabular}


Table 2 - GCMs included in this study.

\begin{tabular}{|l|c|c|l|}
\hline \multicolumn{1}{|c|}{ Modeling Group, Country } & IPCC Model I.D. & Abbrev. & \multicolumn{1}{c|}{ Primary Reference } \\
\hline $\begin{array}{l}\text { Météo-France / Centre National de } \\
\text { Recherches Météorologiques, France }\end{array}$ & CNRM-CM3 & cnrm & Salas-Mélia et al., 2005 \\
\hline CSIRO Atmospheric Research, Australia & CSIRO-Mk3.0 & csiro & Gordon, H.B. et al, 2002 \\
\hline $\begin{array}{l}\text { US Dept. of Commerce / NOAA / } \\
\text { Geophysical Fluid Dynamics } \\
\text { Laboratory, USA }\end{array}$ & GFDL-CM2.0 & gfdl & Delworth et al., 2005 \\
\hline $\begin{array}{l}\text { NASA / Goddard Institute for Space } \\
\text { Studies, USA }\end{array}$ & GISS-ER & giss & $\begin{array}{l}\text { Russell et al., 1995, } \\
2000\end{array}$ \\
\hline $\begin{array}{l}\text { Institute for Numerical Mathematics, } \\
\text { Russia }\end{array}$ & INM-CM3.0 & inmcm & $\begin{array}{l}\text { Diansky and Volodin, } \\
\text { 2002 }\end{array}$ \\
\hline Institut Pierre Simon Laplace, France & IPSL-CM4 & ipsl & IPSL, 2005 \\
\hline $\begin{array}{l}\text { Center for Climate System Research } \\
\text { (The University of Tokyo), National } \\
\text { Institute for Environmental Studies, and } \\
\text { Frontier Research Center for Global } \\
\text { Change (JAMSTEC), Japan }\end{array}$ & MIROC3.2(medres) & miroc & $\begin{array}{l}\text { K-1 model developers, } \\
2004\end{array}$ \\
\hline $\begin{array}{l}\text { Max Planck Institute for Meteorology, } \\
\text { Germany }\end{array}$ & ECHAM5/MPI-OM & mpi & Jungclaus et al.., 2005 \\
\hline Meteorological Research Institute, Japan & MRI-CGCM2.3.2 & mri & Yukimoto et al., 2001 \\
\hline $\begin{array}{l}\text { National Center for Atmospheric } \\
\text { Research, USA }\end{array}$ & PCM & pcm & Washington et al., 2000 \\
\hline $\begin{array}{l}\text { Hadley Centre for Climate Prediction } \\
\text { and Research / Met Office, UK }\end{array}$ & UKMO-HadCM3 & hadcm3 & Gordon, C. et al., 2002 \\
\hline
\end{tabular}


Table 3 - P summary statistics for the Basin 1 Feather River at Oroville. Values in italics are significantly different from the 1961-1990 mean at a $90 \%$ confidence level, based on a 2-sided t-test for differences in the mean. Bold italics differ with $95 \%$ confidence.

\begin{tabular}{|c|c|c|c|c|c|c|c|}
\hline \multicolumn{2}{|c|}{ PRECIPITATION } & \multicolumn{3}{|c|}{ SRESA2 } & \multicolumn{3}{|c|}{ SRESB1 } \\
\hline Month & $\begin{array}{c}1961- \\
1990 \\
\text { Mean, } \\
\mathrm{mm} / \mathrm{d}\end{array}$ & $\begin{array}{c}2011-2040 \\
\Delta, \mathrm{mm} / \mathrm{d}\end{array}$ & $\begin{array}{c}2041-2070 \\
\Delta, \mathrm{mm} / \mathrm{d}\end{array}$ & $\begin{array}{c}2071-2100 \\
\Delta, \mathrm{mm} / \mathrm{d}\end{array}$ & $\begin{array}{c}2011-2040 \\
\Delta, \mathrm{mm} / \mathrm{d}\end{array}$ & $\begin{array}{c}2041-2070 \\
\Delta, \mathrm{mm} / \mathrm{d}\end{array}$ & $\begin{array}{c}2071-2100 \\
\Delta, \mathrm{mm} / \mathrm{d}\end{array}$ \\
\hline Jan & 6.7 & 1.0 & 1.7 & 1.8 & 1.2 & 0.3 & 1.1 \\
\hline Feb & 5.6 & 1.2 & 0.7 & 1.5 & 0.4 & 1.0 & 0.9 \\
\hline Mar & 4.1 & 0.2 & -0.2 & 0.3 & 0.2 & 0.2 & -0.1 \\
\hline Apr & 2.4 & 0.0 & -0.1 & -0.5 & -0.2 & -0.3 & -0.1 \\
\hline May & 1.6 & -0.2 & -0.4 & -0.6 & -0.2 & -0.1 & -0.2 \\
\hline Jun & 0.8 & 0.0 & -0.2 & -0.3 & 0.0 & -0.1 & -0.2 \\
\hline Jul & 0.2 & 0.0 & 0.0 & 0.0 & 0.1 & 0.1 & 0.1 \\
\hline Aug & 0.3 & 0.0 & 0.0 & 0.0 & 0.2 & 0.2 & 0.2 \\
\hline Sep & 0.6 & 0.0 & -0.1 & 0.0 & 0.2 & 0.3 & 0.3 \\
\hline Oct & 1.9 & 0.1 & 0.2 & 0.2 & 0.7 & 0.6 & 0.6 \\
\hline Nov & 4.3 & 0.6 & 0.6 & 0.5 & 0.8 & 0.4 & 0.6 \\
\hline Dec & 5.8 & 1.1 & 1.7 & 1.2 & 0.8 & 0.3 & 0.7 \\
\hline Annual & 2.8 & 0.3 & 0.3 & 0.3 & 0.3 & 0.2 & 0.3 \\
\hline
\end{tabular}


Table 4 - Same as Table 3, but for Basin 4. Kings $R$ at Pine Flat Dam.

\begin{tabular}{|c|c|c|c|c|c|c|c|}
\hline \multicolumn{2}{|c|}{ PRECIPITATION } & \multicolumn{3}{|c|}{ SRESA2 } & \multicolumn{3}{|c|}{ SRESB1 } \\
\hline Month & $\begin{array}{c}\text { 1961- } \\
1990 \\
\text { Mean, } \\
\text { mm/d }\end{array}$ & $\begin{array}{c}2011-2040 \\
\Delta, \mathrm{mm} / \mathrm{d}\end{array}$ & $\begin{array}{c}2041-2070 \\
\Delta, \mathrm{mm} / \mathrm{d}\end{array}$ & $\begin{array}{c}2071-2100 \\
\Delta, \mathrm{mm} / \mathrm{d}\end{array}$ & $\begin{array}{c}2011-2040 \\
\Delta, \mathrm{mm} / \mathrm{d}\end{array}$ & $\begin{array}{c}2041-2070 \\
\Delta, \mathrm{mm} / \mathrm{d}\end{array}$ & $\begin{array}{c}2071-2100 \\
\Delta, \mathrm{mm} / \mathrm{d}\end{array}$ \\
\hline Jan & 6.2 & 1.0 & 2.3 & 1.6 & 1.1 & 0.1 & 0.8 \\
\hline Feb & 5.5 & 1.5 & 0.6 & 0.8 & 0.9 & 0.8 & 0.7 \\
\hline Mar & 4.6 & 0.0 & -0.8 & -0.6 & -0.3 & -0.2 & -0.6 \\
\hline Apr & 2.9 & -0.3 & -0.5 & -1.2 & -0.5 & -0.6 & -0.5 \\
\hline May & 1.6 & -0.3 & -0.5 & -0.8 & -0.2 & -0.2 & -0.4 \\
\hline Jun & 0.7 & 0.0 & -0.2 & -0.2 & 0.0 & -0.1 & -0.2 \\
\hline Jul & 0.4 & 0.0 & 0.0 & 0.1 & 0.1 & 0.1 & 0.2 \\
\hline Aug & 0.3 & 0.0 & 0.1 & 0.2 & 0.1 & 0.2 & 0.2 \\
\hline Sep & 1.1 & 0.1 & 0.0 & 0.3 & 0.2 & 0.4 & 0.3 \\
\hline Oct & 1.3 & 0.0 & 0.1 & 0.1 & 0.2 & 0.1 & 0.3 \\
\hline Nov & 3.8 & 0.4 & -0.1 & -0.1 & 0.6 & 0.1 & 0.4 \\
\hline Dec & 5.3 & 1.1 & 1.2 & 0.8 & 0.7 & 0.1 & 0.1 \\
\hline Annual & 2.8 & 0.3 & 0.2 & 0.1 & 0.3 & 0.0 & 0.1 \\
\hline
\end{tabular}


Table 5 - Confidence that the A2 and B1 mean P and T differ for 2071-2100. Confidence is determined with a 2-sided t-test for differences in mean. Basin numbering is as in Table 1.

\begin{tabular}{|l|r|r|r|r|r|r|r|r|}
\hline & \multicolumn{4}{|c|}{ Precipitation } & \multicolumn{4}{|c|}{ Temperature } \\
\hline Month & Basin 1 & Basin 2 & Basin 3 & Basin 4 & Basin 1 & \multicolumn{1}{c|}{ Basin 2 } & \multicolumn{1}{c|}{ Basin 3 } & Basin 4 \\
\hline Jan & $50 \%$ & $48 \%$ & $51 \%$ & $54 \%$ & $97 \%$ & $98 \%$ & $98 \%$ & $97 \%$ \\
\hline Feb & $51 \%$ & $34 \%$ & $20 \%$ & $6 \%$ & $95 \%$ & $94 \%$ & $94 \%$ & $93 \%$ \\
\hline Mar & $59 \%$ & $37 \%$ & $17 \%$ & $4 \%$ & $59 \%$ & $63 \%$ & $70 \%$ & $71 \%$ \\
\hline Apr & $83 \%$ & $89 \%$ & $93 \%$ & $94 \%$ & $76 \%$ & $81 \%$ & $84 \%$ & $86 \%$ \\
\hline May & $90 \%$ & $90 \%$ & $91 \%$ & $90 \%$ & $94 \%$ & $96 \%$ & $97 \%$ & $97 \%$ \\
\hline Jun & $60 \%$ & $52 \%$ & $54 \%$ & $50 \%$ & $96 \%$ & $96 \%$ & $96 \%$ & $95 \%$ \\
\hline Jul & $70 \%$ & $72 \%$ & $69 \%$ & $66 \%$ & $96 \%$ & $94 \%$ & $94 \%$ & $93 \%$ \\
\hline Aug & $57 \%$ & $35 \%$ & $20 \%$ & $17 \%$ & $99 \%$ & $99 \%$ & $98 \%$ & $98 \%$ \\
\hline Sep & $67 \%$ & $54 \%$ & $34 \%$ & $4 \%$ & $100 \%$ & $100 \%$ & $100 \%$ & $99 \%$ \\
\hline Oct & $54 \%$ & $56 \%$ & $57 \%$ & $58 \%$ & $99 \%$ & $99 \%$ & $99 \%$ & $99 \%$ \\
\hline Nov & $11 \%$ & $34 \%$ & $51 \%$ & $58 \%$ & $98 \%$ & $98 \%$ & $98 \%$ & $97 \%$ \\
\hline Dec & $45 \%$ & $50 \%$ & $54 \%$ & $55 \%$ & $98 \%$ & $98 \%$ & $98 \%$ & $98 \%$ \\
\hline Annual & $6 \%$ & $2 \%$ & $3 \%$ & $8 \%$ & $100 \%$ & $100 \%$ & $100 \%$ & $100 \%$ \\
\hline
\end{tabular}


Table 6 - Monthly and annual mean flow and percent change from the mean for the North (lower elevation) two gauges. Bold and italics signify the same confidence as for Table 2 . Basin numbering is as in Table 1.

\begin{tabular}{|c|c|c|c|c|c|c|c|}
\hline \multicolumn{2}{|c|}{ BASIN 1} & \multicolumn{3}{|c|}{ SRESA2 } & \multicolumn{3}{|c|}{ SRESB1 } \\
\hline Month & $\begin{array}{c}1961- \\
1990 \\
\text { Mean, } \\
\mathrm{m}^{3} / \mathrm{s}\end{array}$ & $\begin{array}{c}2011-2040 \\
\Delta, \% \\
\end{array}$ & $\begin{array}{c}2041-2070 \\
\Delta, \% \\
\end{array}$ & $\begin{array}{c}2071-2100 \\
\Delta, \% \\
\end{array}$ & $\begin{array}{c}2011-2040 \\
\Delta, \%\end{array}$ & $\begin{array}{c}2041-2070 \\
\Delta, \%\end{array}$ & $\begin{array}{c}2071-2100 \\
\Delta, \%\end{array}$ \\
\hline Jan & 258 & $49 \%$ & $83 \%$ & $88 \%$ & $55 \%$ & $40 \%$ & $62 \%$ \\
\hline Feb & 312 & $39 \%$ & $47 \%$ & $66 \%$ & $29 \%$ & $37 \%$ & $48 \%$ \\
\hline Mar & 302 & $23 \%$ & $18 \%$ & $30 \%$ & $22 \%$ & $17 \%$ & $18 \%$ \\
\hline Apr & 299 & $7 \%$ & $2 \%$ & $-6 \%$ & $3 \%$ & $-1 \%$ & $-4 \%$ \\
\hline May & 269 & $-5 \%$ & $-14 \%$ & $-28 \%$ & $-8 \%$ & $-15 \%$ & $-20 \%$ \\
\hline Jun & 182 & $-8 \%$ & $-23 \%$ & $-38 \%$ & $-15 \%$ & $-20 \%$ & $-29 \%$ \\
\hline Jul & 92 & $-5 \%$ & $-16 \%$ & $-25 \%$ & $-8 \%$ & $-13 \%$ & $-15 \%$ \\
\hline Aug & 60 & $-2 \%$ & $-10 \%$ & $-15 \%$ & $-3 \%$ & $-6 \%$ & $-8 \%$ \\
\hline Sep & 46 & $-1 \%$ & $-8 \%$ & $-11 \%$ & $5 \%$ & $4 \%$ & $5 \%$ \\
\hline Oct & 50 & $14 \%$ & $20 \%$ & $23 \%$ & $60 \%$ & $61 \%$ & $49 \%$ \\
\hline Nov & 100 & $25 \%$ & $30 \%$ & $22 \%$ & $34 \%$ & $24 \%$ & $35 \%$ \\
\hline Dec & 189 & $46 \%$ & $53 \%$ & $56 \%$ & $41 \%$ & $32 \%$ & $40 \%$ \\
\hline Annual & 179 & $19 \%$ & $21 \%$ & $21 \%$ & $18 \%$ & $13 \%$ & $17 \%$ \\
\hline \multicolumn{2}{|c|}{ BASIN 2} & \multicolumn{3}{|c|}{ SRESA2 } & \multicolumn{3}{|c|}{ SRESB1 } \\
\hline Jan & 96 & $81 \%$ & $140 \%$ & $129 \%$ & $81 \%$ & $59 \%$ & $87 \%$ \\
\hline Feb & 127 & $62 \%$ & $70 \%$ & $86 \%$ & $46 \%$ & $49 \%$ & $65 \%$ \\
\hline Mar & 126 & $26 \%$ & $7 \%$ & $32 \%$ & $23 \%$ & $9 \%$ & $14 \%$ \\
\hline Apr & 125 & $12 \%$ & $-2 \%$ & $-20 \%$ & $3 \%$ & $-10 \%$ & $-11 \%$ \\
\hline May & 124 & $-11 \%$ & $-23 \%$ & $-44 \%$ & $-13 \%$ & $-26 \%$ & $-32 \%$ \\
\hline Jun & 80 & $-12 \%$ & $-31 \%$ & $-58 \%$ & $-22 \%$ & $-29 \%$ & $-44 \%$ \\
\hline Jul & 35 & $-12 \%$ & $-31 \%$ & $-45 \%$ & $-24 \%$ & $-28 \%$ & $-34 \%$ \\
\hline Aug & 15 & $-2 \%$ & $-13 \%$ & $-20 \%$ & $-5 \%$ & $-6 \%$ & $-10 \%$ \\
\hline Sep & 12 & $1 \%$ & $-7 \%$ & $-10 \%$ & $9 \%$ & $12 \%$ & $11 \%$ \\
\hline Oct & 14 & $34 \%$ & $57 \%$ & $65 \%$ & $118 \%$ & $123 \%$ & $100 \%$ \\
\hline Nov & 33 & $75 \%$ & $80 \%$ & $55 \%$ & $79 \%$ & $47 \%$ & $82 \%$ \\
\hline Dec & 73 & $93 \%$ & $102 \%$ & $96 \%$ & $76 \%$ & $57 \%$ & $55 \%$ \\
\hline Annual & 71 & $32 \%$ & $31 \%$ & $26 \%$ & $26 \%$ & $14 \%$ & $19 \%$ \\
\hline
\end{tabular}


Table 7 - Same as for Table 6, but for the South two gauges at higher elevation.

\begin{tabular}{|c|c|c|c|c|c|c|c|}
\hline \multicolumn{2}{|c|}{ BASIN 3} & \multicolumn{3}{|c|}{ SRESA2 } & \multicolumn{3}{|c|}{ SRESB1 } \\
\hline Month & $\begin{array}{c}1961- \\
1990 \\
\text { Mean, } \\
\mathrm{m}^{3} / \mathrm{s}\end{array}$ & $\begin{array}{c}2011-2040 \\
\Delta, \% \\
\end{array}$ & $\begin{array}{c}2041-2070 \\
\Delta, \%\end{array}$ & $\begin{array}{c}2071-2100 \\
\Delta, \%\end{array}$ & $\begin{array}{c}2011-2040 \\
\Delta, \% \\
\end{array}$ & $\begin{array}{c}2041-2070 \\
\Delta, \%\end{array}$ & $\begin{array}{c}2071-2100 \\
\Delta, \%\end{array}$ \\
\hline Jan & 67 & $62 \%$ & $107 \%$ & $104 \%$ & $57 \%$ & $40 \%$ & $62 \%$ \\
\hline Feb & 76 & $54 \%$ & $68 \%$ & $79 \%$ & $44 \%$ & $41 \%$ & $61 \%$ \\
\hline Mar & 89 & $29 \%$ & $26 \%$ & $53 \%$ & $27 \%$ & $20 \%$ & $35 \%$ \\
\hline Apr & 121 & $22 \%$ & $32 \%$ & $27 \%$ & $27 \%$ & $28 \%$ & $28 \%$ \\
\hline May & 198 & $13 \%$ & $-1 \%$ & $-17 \%$ & $12 \%$ & $-7 \%$ & $-8 \%$ \\
\hline Jun & 148 & $-7 \%$ & $-25 \%$ & $-48 \%$ & $-20 \%$ & $-32 \%$ & $-37 \%$ \\
\hline Jul & 57 & $3 \%$ & $-16 \%$ & $-36 \%$ & $-10 \%$ & $-23 \%$ & $-26 \%$ \\
\hline Aug & 29 & $0 \%$ & $-13 \%$ & $-23 \%$ & $-5 \%$ & $-10 \%$ & $-14 \%$ \\
\hline Sep & 23 & $1 \%$ & $-7 \%$ & $-9 \%$ & $5 \%$ & $7 \%$ & $0 \%$ \\
\hline Oct & 23 & $4 \%$ & $0 \%$ & $9 \%$ & $15 \%$ & $11 \%$ & $15 \%$ \\
\hline Nov & 37 & $30 \%$ & $23 \%$ & $26 \%$ & $35 \%$ & $15 \%$ & $38 \%$ \\
\hline Dec & 57 & $65 \%$ & $66 \%$ & $74 \%$ & $50 \%$ & $32 \%$ & $40 \%$ \\
\hline Annual & 77 & $22 \%$ & $19 \%$ & $14 \%$ & $17 \%$ & $6 \%$ & $11 \%$ \\
\hline \multicolumn{2}{|c|}{ BASIN 4} & \multicolumn{3}{|c|}{ SRESA2 } & \multicolumn{3}{|c|}{ SRESB1 } \\
\hline Jan & 41 & $63 \%$ & $104 \%$ & $116 \%$ & $57 \%$ & $37 \%$ & $61 \%$ \\
\hline Feb & 49 & $66 \%$ & $88 \%$ & $105 \%$ & $54 \%$ & $53 \%$ & $83 \%$ \\
\hline Mar & 54 & $38 \%$ & $45 \%$ & $66 \%$ & $35 \%$ & $28 \%$ & $50 \%$ \\
\hline Apr & 80 & $25 \%$ & $38 \%$ & $37 \%$ & $30 \%$ & $27 \%$ & $34 \%$ \\
\hline May & 140 & $21 \%$ & $12 \%$ & $-2 \%$ & $20 \%$ & $4 \%$ & $3 \%$ \\
\hline Jun & 154 & $1 \%$ & $-16 \%$ & $-44 \%$ & $-12 \%$ & $-28 \%$ & $-32 \%$ \\
\hline Jul & 84 & $-3 \%$ & $-29 \%$ & $-52 \%$ & $-20 \%$ & $-35 \%$ & $-42 \%$ \\
\hline Aug & 32 & $3 \%$ & $-19 \%$ & $-34 \%$ & $-10 \%$ & $-17 \%$ & $-24 \%$ \\
\hline Sep & 23 & $3 \%$ & $-7 \%$ & $-4 \%$ & $14 \%$ & $17 \%$ & $-2 \%$ \\
\hline Oct & 21 & $-1 \%$ & $-7 \%$ & $-6 \%$ & $3 \%$ & $2 \%$ & $0 \%$ \\
\hline Nov & 27 & $21 \%$ & $4 \%$ & $7 \%$ & $23 \%$ & $2 \%$ & $19 \%$ \\
\hline Dec & 37 & $60 \%$ & $60 \%$ & $65 \%$ & $40 \%$ & $29 \%$ & $33 \%$ \\
\hline Annual & 62 & $21 \%$ & $16 \%$ & $8 \%$ & $14 \%$ & $3 \%$ & $6 \%$ \\
\hline
\end{tabular}


Table 8 - Confidence that the mean flow for the A2 and B1 scenarios differ for 2071-2100. Confidence is determined with a 2-sided t-test for differences in mean. Basin numbering is as in Table 1.

\begin{tabular}{|l|r|r|r|r|}
\hline Month & Basin 1 & Basin 2 & Basin 3 & Basin 4 \\
\hline Jan & $68 \%$ & $59 \%$ & $71 \%$ & $77 \%$ \\
\hline Feb & $60 \%$ & $43 \%$ & $45 \%$ & $42 \%$ \\
\hline Mar & $64 \%$ & $53 \%$ & $58 \%$ & $46 \%$ \\
\hline Apr & $18 \%$ & $44 \%$ & $5 \%$ & $9 \%$ \\
\hline May & $59 \%$ & $63 \%$ & $47 \%$ & $23 \%$ \\
\hline Jun & $72 \%$ & $76 \%$ & $63 \%$ & $60 \%$ \\
\hline Jul & $78 \%$ & $61 \%$ & $60 \%$ & $55 \%$ \\
\hline Aug & $85 \%$ & $83 \%$ & $72 \%$ & $67 \%$ \\
\hline Sep & $91 \%$ & $87 \%$ & $70 \%$ & $12 \%$ \\
\hline Oct & $50 \%$ & $39 \%$ & $29 \%$ & $34 \%$ \\
\hline Nov & $35 \%$ & $40 \%$ & $38 \%$ & $52 \%$ \\
\hline Dec & $46 \%$ & $61 \%$ & $60 \%$ & $56 \%$ \\
\hline Annual & $28 \%$ & $25 \%$ & $14 \%$ & $8 \%$ \\
\hline
\end{tabular}


Table 9 - Mean April 1 SWE and percent change. Bold and Italics are used identically to Table 3.

\begin{tabular}{|l|c|r|r|r|r|r|r|}
\hline \multicolumn{2}{|c|}{ April 1 SWE } & \multicolumn{3}{|c|}{ SRESA2 } & \multicolumn{3}{c|}{ SRESB1 } \\
\hline & $1961-$ & & & & & & \\
& 1990 & & & & & \\
& Mean, & $2011-2040$ & $2041-2070$ & $2071-2100$ & $2011-2040$ & $2041-2070$ & $2071-2100$ \\
Basin & mm & $\Delta, \%$ & $\Delta, \%$ & $\Delta, \%$ & $\Delta, \%$ & $\Delta, \%$ & $\Delta, \%$ \\
\hline 1 & 109 & $-21 \%$ & $-42 \%$ & $-69 \%$ & $-29 \%$ & $-42 \%$ & $-59 \%$ \\
\hline 2 & 119 & $-15 \%$ & $-33 \%$ & $-63 \%$ & $-24 \%$ & $-33 \%$ & $-53 \%$ \\
\hline 3 & 302 & $0 \%$ & $-15 \%$ & $-38 \%$ & $-7 \%$ & $-20 \%$ & $-30 \%$ \\
\hline 4 & 354 & $0 \%$ & $-16 \%$ & $-40 \%$ & $-8 \%$ & $-22 \%$ & $-32 \%$ \\
\hline
\end{tabular}


Table 10 - Date of the centroid of the annual flow volume, and the shift in days. Mean is in day of year (January 1=1).

\begin{tabular}{|c|c|c|c|c|c|c|c|}
\hline \multicolumn{2}{|c|}{ Flow Centroid } & \multicolumn{3}{|c|}{ SRESA2 } & \multicolumn{3}{|c|}{ SRESB1 } \\
\hline Basin & $\begin{array}{c}1961- \\
1990 \\
\text { Mean, } \\
\text { day }\end{array}$ & $\begin{array}{c}2011-2040 \\
\Delta, \text { days }\end{array}$ & $\begin{array}{c}2041-2070 \\
\Delta, \text { days }\end{array}$ & $\begin{array}{c}2071-2100 \\
\Delta, \text { days }\end{array}$ & $\begin{array}{c}2011-2040 \\
\Delta, \text { days }\end{array}$ & $\begin{array}{c}2041-2070 \\
\Delta, \text { days }\end{array}$ & $\begin{array}{c}2071-2100 \\
\Delta, \text { days }\end{array}$ \\
\hline 1 & 78 & -15 & -21 & -27 & -17 & -17 & -23 \\
\hline 2 & 84 & -23 & -33 & -38 & -26 & -27 & -34 \\
\hline 3 & 120 & -15 & -25 & -39 & -16 & -19 & -27 \\
\hline 4 & 137 & -12 & -24 & -40 & -15 & -19 & -29 \\
\hline
\end{tabular}




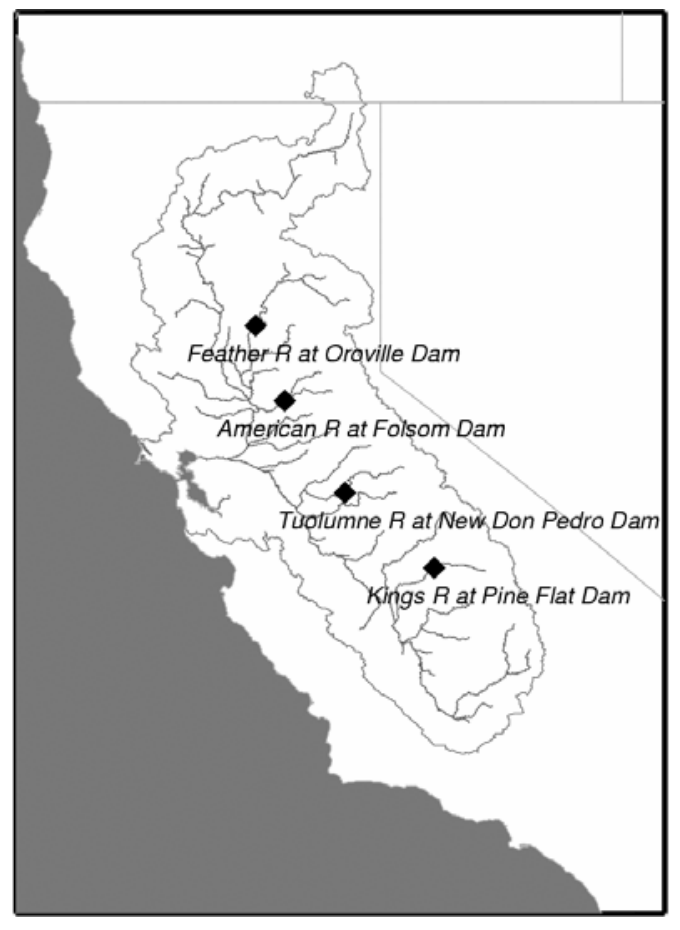

Figure 1 - Location of the outlets to the four basins included in this study. Names indicate the River and the reservoir/dam into which the river discharges 


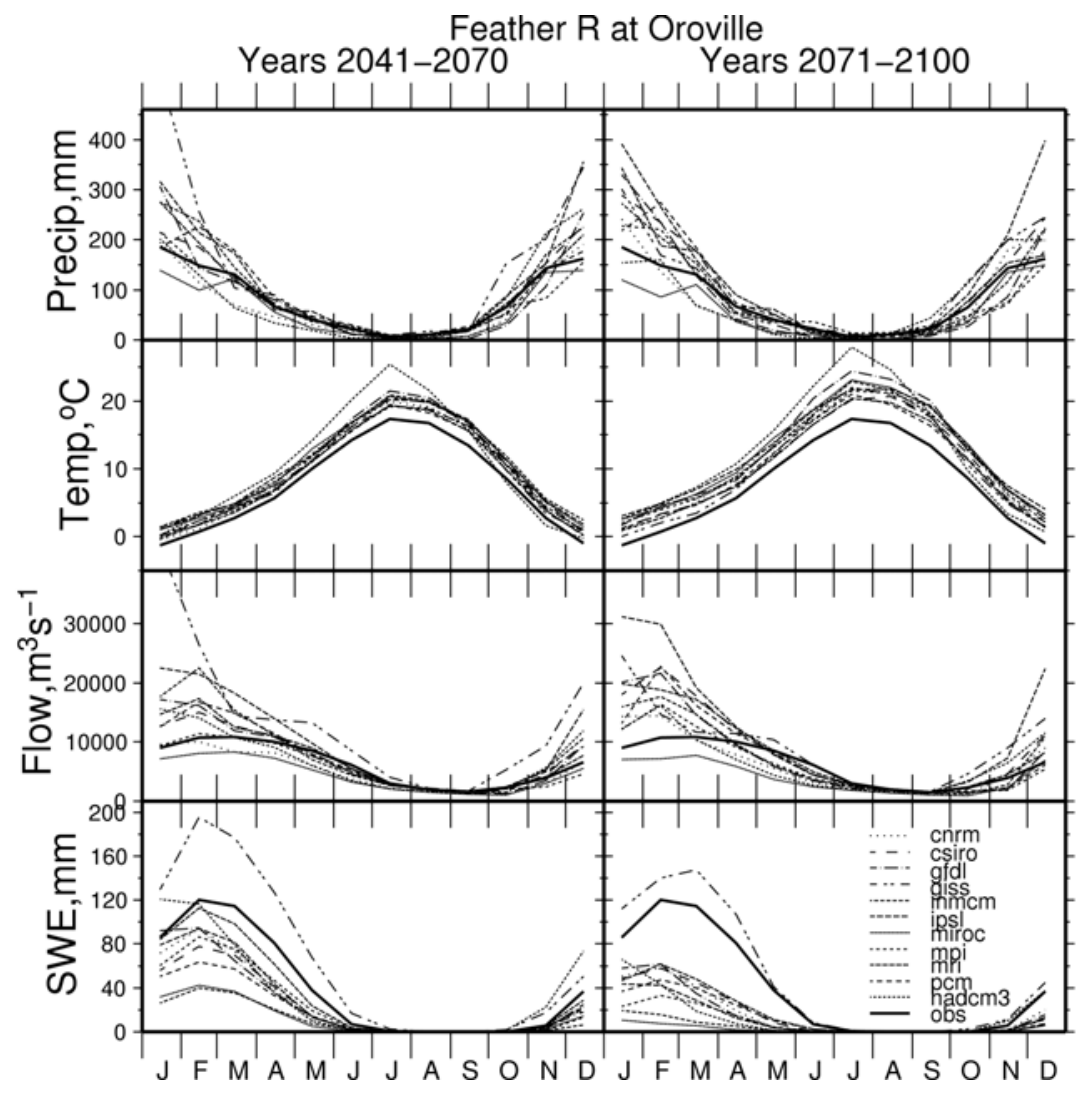

Figure 2 - For one basin, for the SRESA2 scenario, the average precipitation and temperature, streamflow at the outlet point, and basin average snow water equivalent averaged over two 30 -year periods. The thicker line labeled “obs" represents the baseline average for 1961-1990. 